\title{
A Model of Framework for Successive Factors in Islamic Banking System
}

\author{
Fazal Ali Shaikh
}

Department of Economics, University of Sindh, Jamshoro, Pakistan

\begin{abstract}
The core objective of this research was to scrutinize supporting elements of an Islamic banking organization in Pakistan. In the 1970s Islamic banking system emerged as an innovative horizon in the worldwide financial system. Numerous studies have been carried by researchers to know problems related to the Islamic banking system across the globe. The Islamic banking sector "IBD" was established on September 15, 2003. The department was assigned a task for the promotion and evolving of banking provisions with the fulfillment of Islamic laws. The growth of the Islamic banking system in the last five years is laudable. In the form of a survey applying a quantitative approach, the questionnaire is used for collecting the data in this study. A total of three hundred seventy-one (371) participants have taken part in the study. Several analytical methods such as descriptive statistics, factor analysis, and regression were used to evaluate the data and test the model.
\end{abstract}

Keywords: Successful factors, Islamic Banking of Pakistan.

\section{INTRODUCTION}

The organization of Islamic banking is credited with an evolving segment of the worldwide monetary market; with enormous potential, it is growing at a fast pace in all over the world (Nizar, 2015). In comparison to other banks Islamic banks established and obtained a prominent market share from its competitors. Islamic banks are functioning in the Muslim world more specifically in the following country with a certain percentage: $7 \%, 14 \%$ and $28 \%$ in Malaysia, Kuwait and Saudi Arabia correspondingly. It is estimated that in the ensuing decade the organizations of Islamic banks will be reserving approximately forty to fifty (40-50) of the sum of the world of Muslims. Islamic banks illustrating stress on the internal markets whereas Western traditional institutions such as Merrill Lynch International a greater net value (Basheer et al., 2018).

A state such as Pakistan is acknowledged as the originator of complete Islamization; the country initiated the module of Islamic banking in the 1950s. it was the period when the experts of the economy were contemplating the philosophy of the prevailing Islamic system in the country. Pakistan emerged as a pioneer from enacting the complete monetary system in the state. After the two decades, it has come to know to governmental bodies that they still following the British law of economies in the country, moreover, it was not an easy task to transform at a fast pace. The prevailing contemporary system was impeding to establish an entire Islamic monetary system as they intended to alter the system in a very short period. In 1992 the Federal Shariat Court (FSC) declared that the banking system administrating on interest code is non-Islamic, and therefore, it must forbid. As a final point, in 2001, a result was announced to eliminate usury "Riba" from the state's banking system.

The core purpose of this paper is to aware Pakistani clients to give importance whilst electing Islamic banking hence, we take Islamic banking as reliant and religious client choice manner, product plus provision client service, Excellency, the role of communication and the client ease as (independent variables).

\section{PREVIOUS STUDIES}

This part, nature and have an effect on factors that influence the bank institutes internationally are discussed comprehensively.

\subsection{Religion}

Research carried by (Aaminou et al., 2017) found theological belief plus community necessity were two wellknown essential aspects that determine the criteria for selecting the bank. The scrutinized the foremost factors that inspire people "customers" to deal with the system based on Islamic banking. Researcher identified that the criteria for choosing Islamic banking greatly depend on the collective existence of financial and Islamic significance and best service standard of provisions provided in respective bank. Another study carried by (Manzoor et al, 2010) that Pakistan on the Islamic banking expansion dimensions. The findings, the religion was the chief element for increasing that happened to other contributing factors. According to (Mohammed et al., 2019; Nizar, 2015) study, the clients' concerns about the existence of Shariah were the prominent aim for choosing this bank. Furthermore, out of the findings, they concluded the goodwill of the institute as the core factor that affects the 
excellent of clients regarding the selection of kind of banking institutions. The study conductors reported that religion-based influence as the second most important factor that influences customers' selection of the institutes (Khan\&Rehman, 2018) reported that the financial comprehension is the most influential determiner after religion regarding the selection of interest- free banking system.

Financial privileges (margin on the amount, financial investment). (Setiawan et al., 2017) study to select a particular bank that follows with selecting principles of expenditure and profits. It encompasses the margin rate plus returns as the five utmost factors of choosing a bank. The scholars have reported that margin or profit on the merchandise rendered by Islamic Banking branches rendered like the core reason for reliability between the proportion of clients\& Islamic Banks. (Yungucu \& Saiti, 2016) found that interest margin is enduringly been significant as the key interest in the clarification of separate economic behavior. Islamic banks utilize as mediators as accommodating assets or resources to be a principal since financing on the basis of allocation benefits plus and the losses. The research carried out by (Jamil, 2017) those consumers who hold prolonged associations with the banks were found valuable at a greater level in comparison to those who keep a short-range association.

\subsection{Goods and Services}

Tsai (2017) found that supervising clients' courses plus the Excellency of services in general considered one of the prominent causes of evolving a high position in provision activities also enhancing the achievements of the branches. (Yungucu \& Saiti, 2016) concluded that clients give preference great moreover, the banks with good reputation upon these customers are willing to change banks the banks that offer them excellent quality in terms of production plus quality. A piece of research by (Jamil, 2017), recommended that clients of Islamic banking have a scarcity of information regarding the product being rendered by the branches of Islamic banking. For instance, Ijara, Murabaha, finances plus Musharakah. It shows that Islamic banking branched is supposed to take into account, make aware of their customers regarding the product rendering. Akram, Rafique\&Alam (2011) argued that certain inventions to facilitate are being presented by full-fledged customer Service excellence "Rapid and Effective Services" is considered as a customer sensitivity regarding the inadequacy or advantage of any institute plus it's rendered facilities (Omar, 2016). (Tsai, 2017) research was carried out over a large also enormous corporation firm of South Africa. The specific aim of the study was to find the elements that determined the fundamentals of business customers whilst choosing the banking branch. Researchers concluded the class of service is the founding element in establishing an association between business clients plus the banking institutes that they avail themselves. Dusuki \& Abdullah (2007) highlighted in their study Excellency of service plays a decisive role in selecting the bank. The Excellency of services encompasses treating clients in an honorable fashion. It is crucial to recognize the significance of service values that are being presented by any bank to its clients that could significantly persuade client approval to the banks. Siddiqi, (2011) conducted a scientific study in the retail bank's segment in the Bangladeshi context. Media communication announcement communiqué is the ability to render trustworthy knowledge in a well-timed manner (Ndubisi, 2007).

A task to communicate is to bring wakefulness, encourage involved clients plus motivate then enough for initiating a buying decision. The communication also renders what kind of measurements the firm is taking to rectify the causes of being dissatisfaction. A vigorous communication of the institute with its customers will take to better associations moreover, the clients will be sincere and devoted to their course of study, (Aziz et al., 2019) stated that religious terms could be utilized in addition to draw and persuade the customer to the religious' products besides services. Clients to the inventions "products" besides services plus the advertising of items they are offering. Elaborated on the consequence of media communication commercial over the choice of banking criteria also put media communication ad like the fourth criteria on the inventory. The researchers concluded that there was a depressing but irrelevant association between prosperity and promotions. They marked the benefits of media communication promotions in the banks' division regardless it was Islamic Banking or the traditional Banking.

\subsection{Convenience}

Factor similar to suitable to advance the branches Islamic Banking remained the second most historic element. The investigator combined the product cost with the handiness aspect also projected a part is known as "convenience plus the price of products" also stated it the second most important factor pursuing the "status plus service delivery" dimension. (Hassan et al., 2019) stated handiness considered the first criterion to choose a banking institute. In addition to this, Siddiqi (2011) found that convenience plus the efficiency of the banks are the two momentous features to make them satisfied.

\subsection{Hypothesis}

$\mathrm{H}_{1}$ : A relationship among Islamic \& Religion Banking system. $\mathrm{H}_{0}$ : No any relation among Islamic \& Religion Banking system

$\mathrm{H}_{1}$ : A relationship among Islamic Banking \& Cost Benefits 
$\mathrm{H}_{0}$ : No any relationship among Islamic Banking \& cost Benefits $\mathrm{H}_{1}$ : A relationship among Services\& Product offered in Islamic Banks

$\mathrm{H}_{0}$ : No any relationship among Services and Product and Islamic Banks

$\mathrm{H}_{1}$ : A relationship among Islamic Banking \& Customer Service Quality

$\mathrm{H}_{0}$ : No any relationship among Islamic Banking system \& Customer Service Quality.

$\mathrm{H}_{1}$ : A relationship among Islamic Banking system \& Mass media commercial

$\mathrm{H}_{0}$ : There is no any relation to among Islamic Banking \& Mass Media commercials.

$\mathrm{H}_{1}$ : A relationship among Islamic Banking \& Convenience

$\mathrm{H}_{0}$ : No any relationship among Islamic Banking \& Convenience.

\section{METHODOLOGY \& FINDINGS}

To know supporting elements of Islamic banks that requires utilized person correlation test and everyday leastsquare plus.

\section{RELIABILITY TEST}

For collecting the date, the two papers survey is used the survey divided into two sections the first segment is regarding backgrounds the second segment gauges the elements that influence Pakistan Islamic banks. Utilizing a five-point liker scale, participants were requested to respond to answer 32 questions. In the beginning, the sample incorporated all the Islamic banking clients present in the second largest city of Pakistan, "Laharo" as the study has time limitation, therefore, the final sample of 500 hundred clients chose out of the designed sample in those numbers 371 were from actual sampling. The reliability test was conducted by applying SPSS and the value of Cronbach's was extracted. The below figures illustrated Cronbach's value for every variable that is being measured in this study. In the study, Cronbach's is more than the standards which are 0.7 to all the variables.

\section{DESCRIPTIVE ANALYSIS}

A statistical overview of the participants' sex; the majority of respondents were "male" while the $25 \%$ proportion of "female". Right side is showing the bar chart of sex is highlighted "figure 2" approximately sixty-two (62) percent of the participants listed in the range of 22 to 30years ago. Hence, the minimum ratio of participants comes within the limit of 31 to 40 years of age that makes $24 \%$ of the total sample. Regarding material status $41 \%$ of the participants are marital; $59 \%$ are single. The ratio of single participants is higher than the married participants. The outcome of the professional participants is $41 \%$. The ratio of student participants was $38 \%$ of the total sample, while $14 \%$ of the sample has come from the private sector moreover; $7 \%$ of the participants are freelance.

The majority of the participants are educated as they are $56 \%$ of the total sample, while $73 \%$ of the sample is at the master that level since a greater trend of professional education in the participants. Findings in association with banks illustrate the participants associated with a respective Islamic bank. $40 \%$ of the participants were associated with their firms from within a period of three years. It gives the sense the system of Islamic is yet new to the people of Pakistan. Though the system is familiar to the people of Pakistan right from 2004, yet the people are getting familiar with the system. Twenty-seven $\%$ of the people are using Islamic banking within the period of one year; it is an optimistic gesture for Islamic banking firms since people are evolving their interest in the manner of Islamic banking. Moreover, 28 percentage of the participants are persons who are getting services from the Islamic banks from time frame of three to eight years that makes sense that they associated themselves with the banks when it was evolving phase in the country.

\section{CORRELATION}

It applied to measure the relationship among inconsistent. To analyze the association researchers make suppositions better known "hypothesis". In correlation Table 1, the religious element has zero correlation as $p$-value $=0.061$ that is higher than 0.05. Correlation is 0.197 that is illustrating a positive direction amid the variables, yet the strength of the relationship is weak. The p-value of religion element plus invention or product provisions presented is 0.003 that is lower than 0.05 , hence, their existence connections amid those variables. The results of Correlation are 0.281 which demonstrates a positive yet weak correlation. The value of correlation is 0.144 that demonstrates a positive path amid the variables, yet the potency of the relationship is weak.

\section{REGRESSION}

All the variables are less than 0.05; in the coefficient of the specific value, therefore, there is connection amid the variable. For testing the credibility of the framework, researchers believe the particular value that is 0.006 that is lesser than 0.05 hence the relationship is good. The $F$ value in Table 2 is 3.412; therefore, the module is a well fitted to a value 3.412. The accustomed $\mathrm{R}$ square worth in the Model outline with the intention of in what ratio the independent variable added to the dependent variable. Over here the accustomed $\mathrm{R}^{2}$ value is $=0.474$ so as to is a $47 \%$ dependence coefficient. The outcomes of every variable complement to their mode plus mean worth measured with $1=$ strongly disagree to $5=$ strongly agree. The supreme feature that the 
participants have chosen is the client service feature (mean=3.8940). It specifies that the public would appreciate good quality clients' service excellence as it draws them for selecting a definite Islamic bank. In addition to this, regression outcomes and demonstrate that client service Excellency has an optimistic yet momentous influence on Islamic banking customers also the outcomes are consistent with Rustam, Bibi, Zaman, Rustam\&Haq (2011); (Siddiqi,(2011).

The study connected to religious aspect on the second most demanding feature by the participants along with mean 3.04 this plus regression outcomes collectively assure that religion has momentous on clients' preference for Islamic banks versus traditional banks plus outcomes are encompass with previous researches of Marimuthu, Jing, Gie, Mun\&Ping (2010); Dusuki\&Abdullah (2007); El Nagar \& El Biely(2011); and Manzoor, Aqeel\&Sattar (2010). The public ranged cost advantages over the third number (mean=3.506), therefore, monetary privileges magnetize clients' for selecting a bank. Moreover, regression illustrates a positive noteworthy consequences that confirm on the hypothesis that there is some connection between Cost Benefits plus Islamic Banking system in Pakistan, hence, findings are encompassed with studies of Marimuthu, Jing, Gie, Mun\&Ping (2010); Haron\&Ahmad (2000); Kaleem\&Isa(2009); and Hin, Wei, Bohari\&Zainol(2011).

The service of products are being offered also convenience factors carried the similar mean values plus both are specifically also positively associated with Islamic banking, outcomes are included with the previous outcomes of Hossain et al., 2019; Mohammed at al., 2019.The entire Multimedia promotions (MMA) is on the least preference for the customer of Islamic banking (mean=3.0617) as illustrated in Table 3, hence, if we observe closely at regression outcomes it demonstrates a constructive plus particular association between MMA plus Islamic banking also findings are encompassed with the outcomes of Ndubisi(2007); Haque, Ahmed \&Jahan (2010); and Rustam, Bibi, Zaman, Rustam\&Haq(2011).

The outcomes show the attitude of Pakistani customers regarding Islamic banking is more tending to Excellency of services theological viewpoint plus monetary advantages towards product and provisions; less tend to convenience and promotions. Finally, the study shows the public has little awareness regarding the Islamic banking method in Pakistan. The mean 3.0617 illustrates that the public has unbiased reflection concerning this system. People know that the Islamic banking system prevailed in the county yet is familiar to the operations, (Aaker et al., 2001).

\section{CONCLUSION}

The Islamic banking system, not intend to depend on marketing techniques to draw only clients who are with the religious bend of mind, the customers who believe Islam only for using financial firms. The historic notions that have acknowledged in table number three " 3 " of the numerous banking institutes selecting criteria stressed on the demand for Islamic banking to establish and strengthen the Excellency its provisions that is now, deemed the main factor that highlights the difference amid the competitiveness of the branches. Moreover, the outcomes of the study show the matter and provisions of Islamic banking got a unique scale in the banking arena of Pakistan. The margin distribution standard is the only code that can substitute the factor of interest in the Islamic banking method. Moreover, the prominent issue that needs to be taken into account and that is the demand to spread education and awareness amid public in order to disseminate significant traits that the system of Islamic banking have also the distinguishing traits fruitfully synchronize to the needs of clients' in monetary dealings. The below stated are some of the recommendation and suggestions according to the outcomes of the study:

1. The Islamic banking system has one of the outstanding features of the existence of moral and ethical values along with the functions of banking. Signifying those values towards the people can obtain the objective of them to the system of Islamic banking.

2. Islamic banking institutes need to appoint learned Islamic scholars, in order to enhance the financial system as the system has a scarcity of such qualified scholars.

3. In order to penetrate into the traditional market, the institutions of Islamic banking need to work together with diverse Islamic firms and develop the assurance of numerous theological representations for disseminating the utilization of the "RIBA" free system.

\section{REFERENCES}

[1] Aaker, D.A., Kumar, V. \& Day, G.S. (2001). Marketing research (Seventh Edition). New York, USA: John Wiley \& Sons.

[2] Aaminou, M. W., \&Aboulaich, R. (2017). Modeling consumers' behavior in new dual banking markets: the case of Morocco. Review of Pacific Basin Financial Markets and Policies, 20(02), 1750009.

[3] Ahmad, W.W., Rahman, A.A., Ali, N.A. \&Seman, A.C. (2008). Religiosity and banking selection criteria 
among Malays in Lembah Klang. Shariah Journal, 16(2), 279-304.

[4] Aziz, A. A., Rahin, N. M., \&Asri, N. M. (2019). Halal Advertising on Facebook: A Case Study of Health and Beauty Products in Malaysia. In Management of Shari'ah Compliant Businesses (pp. 177-192). Springer, Cham.

[5] Basheer, M. F., KhorramI, A. A. A., \& Hassan, S. G. (2018). Patronage factors of Islamic banking system in Pakistan. Academy of Accounting and Financial Studies Journal.

[6] Dusuki, A.W. \&Abdullah, N.I. (2007). Why do Malaysian customers patronize Islamic bank? International Journal of Bank Marketing, 25(3), 142160.

[7] Hassan, M. K., Rashid, M., \& Aliyu, S. (Eds.). (2019). Islamic Corporate Finance. Routledge.

[8] Hossain, M. S., Yahya, S. B., Rahman, S., Sobhani, F. A., \& Rahman, R. (2019). Corporate Social Responsibility in Healthcare: A case of Islamic Banks (IBs) in Bangladesh. Bangladesh Journal of Medical Science, 18(3), 567-573.

[9] Islamic Banking Bulletin. (2012). Retrieved April 28, 2012, from State Bank of Pakistan: http://www.sbp.org.pk/ibd/bulletin/2012/IBB-March2012.pdf

[10] Jameel, S. A. (2017). CUSTOMER'S AWARENESS TOWARDS THE ISLAMIC BANKING SYSTEM Case Study on Selected Banking in Duhok CityKurdistan Region. Humanities Journal of University of Zakho, 5(1), 230-238.

[11] Kaleem, A. \&Isa, M.M. (2009). Causal relationship between Islamic and conventional banking instruments in Malaysia.

[12] Kasri, R.A. \&Kassim, S.H. (2009). Empirical determinants of saving in the Islamic banks: Evidence from Indonesia.

[13] KHAN, A., \& RAHMAN, A. (2017). Impact of Islamic Motives, Customer Profitability and Service Quality on Customer Satisfaction from Islamic Banks. Development.

[14] Mohamed, J., Azim, Z. A. Z., Yulia, A., \&Rajiain, M. E. (2019). Key Drivers Of Islamic Banking Acceptance In Selangor. International Journal of Accounting, 4(22), 110-115.

[15] Muhammad, A. M., Basha, M. B., \&AlHafidh, G. (2019). UAE Islamic banking promotional strategies: an empirical review. Journal of Islamic Marketing.

[16] Ndubisi, N.O. (2007). Relationship marketing and customer loyalty. Marketing Intelligence \&Planning, 25(1), 98-106.
[17] Nizar, S.M.R. (2015). Consumer attitudes and purchase intentions toward Islamic banks: The influence of religiosity.

[18] Omar, W. A. W., \& Rahim, H. A. (2016). Perception of Non-Muslims towards Islamic banking revisited: SEM approach. Mediterranean Journal of Social Sciences, 7(1), 139.

[19] Organizational Research Methods, 11(3), 419-429.

[20] Rustam, S., Bibi, S., Zaman, K., Rustam, A. \&Haq, Z.U. (2011).Perceptions of corporate customers towards Islamic banking products and services in Pakistan. The Romanian Economic Journal, 41, 107123.

[21] Salman, A., Nawaz, H., Bukhari, S. M. H., \& Baker, A. (2018). Growth analysis of Islamic banking in Pakistan: A qualitative approach. Academy of Accounting and Financial Studies Journal, 22, 1-8.

[22] Setiawan, B., \& Panduwangi, M. (2017). Measurement Of Islamic Banking Attributes In Indonesia. In Proceedings of the Global Conference on Business and Economics Research (GCBER) (Vol. 1415).

[23] Siddiqi, K.O. (2011). Interrelations between service quality attributes, customer satisfaction and customer loyalty in the retail banking sector in Bangladesh. International Journal of Business and Management, 6(3), 12-36.

[24] Smith, M.E., Biddle, K.G. \& Locke, K. (2008). Working with pluralism: Determining quality in qualitative research.

[25] Tsai, M. C., Tsai, M. T., \& Lin, S. C. (2017). Investigating satisfied but disloyal business customers-Case of air express market. Publication name, 60.

[26] Yungucu, B., \&Saiti, B. (2016). The effects of monetary policy on the Islamic financial services industry. Qualitative Research in Financial Markets, 8(3), 218-228.

[27] Zikmund, W.G. (2000). Business Research Methods (Sixth Edition). USA: Dryden. 


\section{APPENDIX}

Tables and Figures

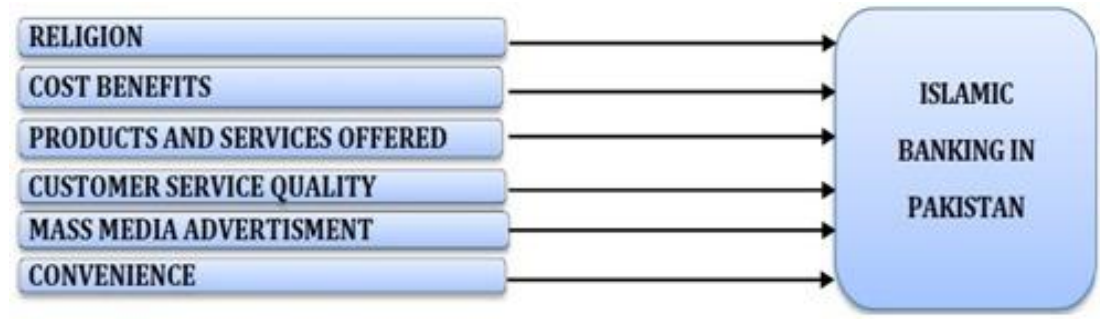

Figure 1: Theoretical Model

Table 1: Model Summary

\begin{tabular}{|c|c|c|c|c|}
\hline \multicolumn{2}{|c|}{ MODEL SUMMARY } \\
\hline Model & R & R Square & Adjusted R Square & Std. Error of the Estimate \\
\hline 1 & $0.617^{\mathrm{a}}$ & 0.474 & 0.120 & 0.006 \\
\hline a. Predictors: (Constant), CCF, RFF, CBF, CSQF, PSOF, MMAF & \\
\hline
\end{tabular}

Table 2: Results of ANOVA analysis

\begin{tabular}{|c|c|c|c|c|c|c|}
\hline \multicolumn{7}{|c|}{ ANOVA } \\
\hline \multirow{4}{*}{1} & Model & Addition of Squares & Df & Value of Mean Square & Value of $\mathbf{F}$ & Value of Sig. \\
\hline & Result of Regression & 8.741 & 7 & 1.421 & 3.502 & $0.006^{\mathrm{a}}$ \\
\hline & Residual & 39.035 & 95 & 0.522 & & \\
\hline & Overall & 45.836 & 98 & & & \\
\hline $\mathrm{F}: \mathrm{i}$ & pendent variable & & & & & \\
\hline
\end{tabular}

Table 3: Results of Coefficients

\begin{tabular}{|c|c|c|c|c|c|c|}
\hline & \multirow{2}{*}{ Model } & \multicolumn{2}{|c|}{ Unstandardized Coefficients } & \multirow{2}{*}{$\begin{array}{c}\begin{array}{c}\text { Standardized } \\
\text { Coefficients }\end{array} \\
\text { Beta }\end{array}$} & \multirow[b]{2}{*}{$\mathbf{T}$} & \multirow[b]{2}{*}{ Sig. } \\
\hline & & $\mathbf{B}$ & Std. Error & & & \\
\hline \multirow{7}{*}{1} & (Constant) & 0.911 & 0.724 & & 1.324 & 0.187 \\
\hline & RFF & 0.217 & 0.167 & 0.291 & 2.874 & 0.014 \\
\hline & $\mathrm{CBF}$ & 0.138 & 0.247 & 0.122 & 1.147 & 0.002 \\
\hline & PSOF & 0.087 & 0.247 & 0.082 & 0.661 & 0.004 \\
\hline & CSQF & 0.089 & 0.201 & 0.081 & 0.897 & 0.055 \\
\hline & MMAF & 0.217 & 0.157 & 0.134 & 0.991 & 0.214 \\
\hline & $\mathrm{CF}$ & 0.033 & 0.121 & 0.047 & 0.401 & 0.321 \\
\hline
\end{tabular}


Citation of this Article:

Fazal Ali Shaikh, "A Model of Framework for Successive Factors in Islamic Banking System” Published in International Research Journal of Innovations in Engineering and Technology - IRJIET, Volume 4, Issue 9, pp 31-37, September 2020. https://doi.org/10.47001/IRJIET/2020.409005 